\title{
A theory of the abuse of History
}

Uma teoria do abuso da História

Antoon De Baets*

\section{RESUMo}

Este ensaio pretende esboçar uma teoria coerente sobre o abuso e o uso irresponsável da história. Ainda não existe de forma acabada uma teoria como essa, com a qual historiadores possam identificar, provar, explicar e avaliar abusos da história. O texto começa com uma discussão sobre a delimitação do problema, ou seja, como distinguir uma história irresponsável e abusiva, de um lado, de uma história perigosa, não científica, incompetente, nociva e desprovida de sentido, de outro. Em seguida, define-se o abuso da história como a sua utilização com o intuito de ludibriar, e o conceito mais amplo de uso irresponsável da história como o seu uso negligente ou enganador. Finalmente, vários desdobramentos da teoria serão desenvolvidos, desde uma tipologia dos abusos e dos usos irresponsáveis, questões relativas a sua evidência, explicação e avaliação, até medidas para sua prevenção.

Palavras-chave: história abusiva; problema de demarcação; história irresponsável; história responsável.

\section{Abstract}

This essay is an attempt to sketch a coherent theory on the abuse and irresponsible use of history. Such a general theory, which enables historians to identify, prove, explain and evaluate abuses of history, does not yet exist. The essay opens with a discussion of the demarcation problem, that is the problem of how to distinguish irresponsible and abusive history on the one hand from nonscientific, incompetent, meaningless, harmful, and dangerous history on the other. It then proceeds to define the abuse of history as its use with intent to deceive and the broader concept of the irresponsible use of history as either its deceptive or negligent use. Finally, the various ramifications of the theory are developed, from a typology of abuses and irresponsible uses, over questions of evidence, explanation and evaluation to measures of prevention.

Keywords: abusive history; demarcation problem; irresponsible history; responsible history.

${ }^{*} \mathrm{PhD}$ in History, University of Ghent, Belgium (1988). History Department, University of Groningen (Rijksuniversiteit Groningen). P.O. Box 716 - 9700 AS Groningen - The Netherlands. a.h.m.de.baets@ rug.nl 
For who does not know history's first law to be that an author must not dare to tell anything but the truth? And its second that he must make bold to tell the whole truth? That there must be no suggestion of partiality anywhere in his writings? Nor of malice?

Cicero $^{1}$

It shall defend freedom of thought and expression in the field of historical research and teaching, and is opposed to the misuse of history and shall use every means at its disposal to ensure the ethical professional conduct of its members.

International Committee of Historical Sciences, Constitution ${ }^{2}$

The abuse of history is frequently dangerous. It is common under dictatorships and in periods of gross human rights violations. It played a major role during the genocide in Rwanda (1994) and the wars in the former Yugoslavia (1991-1995). Although the natural habitat of the abuses of history is a nondemocratic environment, its persistent traces are also present in many democracies. Not so long ago, religious tensions in India (1998-2004), for example, were partly incited by divergent and distorted views of the past. How can we delineate, with some certainty, the boundaries of this problem? This is possible only if we have a theory that provides an insight into what exactly happens when history is abused and into how such conduct should be judged.

Strangely enough, such an encompassing theory does not yet exist. This is so because many historians who are informed about cases of abuse - often historians living in dictatorial countries or their colleagues who were allowed to visit them - do not want to write about the abuses because they fear research or career troubles or backlash effects on themselves or their wider circle. The result is wide underreporting, with the subject mentioned only in passing. Even if historians find the courage to report about it, they often lack time to make the evidence conclusive, while those who do find time to become whistleblowers are frequently more fascinated by the painful details of the individual case they are describing and defending rather than by the similarities to other cases. In addition, they generally encounter much disbelief. If they do seek patterns, they rarely have more than a few cases at their disposal, or they only use cases that represent one dimension or type of abuse, thereby hindering broad generalizations and a global view. That is why so many 
essays about the abuse of history commonly describe the political context of historical writing in certain, often dictatorial, countries. This is useful, but for purely practical reasons.

Even theoretical works broaching the subject are captivated by an inductive approach. They usually describe history as an instrument legitimizing ideology and power (which it often is), but do not systematically test a theory against the abuses they analyze. ${ }^{3}$ Only the classic works on the methodology of history and their successors pay some theoretical attention to the question of abuse, specifically in the discussion of the so-called 'internal criticism of the lie and the error' (by which the lies and errors of source producers, not of professional historians, are meant), or in the mention of various series of nonscientific motives for the writing of history. Such considerations, however, are seldom supplemented with theoretical reflections on conduct and intention, or with the notions of harm and wrongdoing.

\section{A Note on Scholarship and Profession}

When I expound my theory in the lines that follow, I take it for granted that, foremost among several parties, recognized associations of professional historians working under democratic conditions have the authority and duty to decide whether a given use of history is an abuse. My theory is developed to guide them in this area. And if it concentrates mainly on abuses by professional and academic historians, others will obviously benefit from a demonstration of how the profession looks or might look at abuses of history. Clearly, these abuses are only a subgroup of misconduct by professional historians. Misconduct is broader than abuse of history as the former also encompasses violations of professional norms not specifically related to history, such as the abusive reaction to reasonable guidelines from the academic management, the use of offensive language in the lecture room, or the intimidation and discriminatory treatment of colleagues and students.

From the outset, I have to clarify the concepts of historical scholarship and the historical profession. These are very close concepts, frequently used intermingled (also here), but they are not synonyms. Scholarship concerns questions of content and method, questions of truth, and reliable expert knowledge. As such, scholarship is the decisive condition for the profession. 
The profession itself concerns the organizational aspects of scholarship. Although operating under widely divergent conditions across countries, the organizational aspects are quite universal. They are built on two antagonistic core values: autonomy and accountability. Professorial and institutional autonomy is the power to control the academic environment. This includes control of the four pillars on which this environment rests: the curriculum, the awarding of degrees, the admission of students, and the recruitment (selection and promotion) of staff. By accountability, it is meant that universities and their personnel be publicly answerable to the society in which they work. For the moment, it is sufficient to keep the distinction between scholarship and profession in mind. ${ }^{4}$

History is an important, dangerous, and fragile subject. As a universal phenomenon, the abuse of history is infinite in its variety in amount and degree. It is a well-known and obvious area of interest, but at the same time, it is also an underestimated and neglected topic of theoretical research. In 1985, the Slovak Miroslav Kusý, a dismissed philosopher-turned-unskilled worker under 'normalization,' complained that famous historians, like Marc Bloch and Edward Carr, did not pay any attention to the difficulties and risks of the historical profession and the historian's vulnerability in their highly acclaimed works on the methodology of history. ${ }^{5}$ Sadly, both were very vulnerable themselves and became victims of censorship and repression. Carr's multivolume History of Soviet Russia has been banned in the Soviet Union for four decades. Bloch's name disappeared from the cover of the Annales during the German occupation of France (although he continued to contribute under a pseudonym); he died at the hands of the Gestapo near Lyons in $1944 .^{6}$

\section{DemarCATIONS}

It is history that can be abused, not the past. Sources from the past and facts and opinions about the past can be intentionally distorted. But the past itself cannot be affected by acts in the present.

Abusive history is continuously confused with other types of history. ${ }^{7}$ Table 1 attempts to list some distinctions. Termed demarcations, the boundaries of these distinctions are not clear-cut. 
The demarcation between scientific and nonscientific history is, first of all, epistemological, that is, it concerns questions of truth. I profoundly share the views of the sociologist Edward Shils (1910-1995) on truth. A professor at the University of Chicago and the founder of Minerva: A Review of Science, Learning and Policy in 1962, he was one of the world's leading experts on higher education and academic freedom. His memorable defense of the academic ethic begins as follows:

Universities have a distinctive task. It is the methodical discovery and the teaching of truths about serious and important things ... That truth has a value in itself, apart from any use to which it is put, is a postulate of the activities of the university. It begins with the assumption that truth is better than error. ${ }^{8}$

In the philosophy of science, many theories distinguishing truth from error (including falsity) have been defended. Insights into the epistemological demarcation problem have changed over time and none of the theories has ever gained universal acceptance. I will use one of the theories best suited to the needs of historians (and also perhaps the most famous) - the one expounded by Karl Popper. According to Popper, the central question is whether a given theory - here, a theory about past events - is falsifiable or not, in other words whether a test can be developed to reject that theory. Such a test investigates the relationship between the theory, the available sources, the method applied, and the logic of the argument. The test result decides the status of the theory. A theory before the test is prescientific. If the theory passes the test, it is provisionally accepted as scientific. If it is rejected (that is, if it is not testable or if it does not pass the test), it acquires the status of nonscientific history. When a theory that has been provisionally accepted is tested again with other data or other methods, and rejected after this new test, it receives the status of exscientific history. ${ }^{9}$ History that turns out to be of the pre-, non- or exscientific kind is not meaningless. On the contrary, as part of ideologies, myths, legends, or beliefs about the world, it may provide meaning for those who hold such beliefs. ${ }^{10}$ As conjecture, this type of history may anticipate or inspire future scientific theories. However, as long as it does not pass the test, this 'history' is not scientific history.

Another demarcation is drawn simultaneously with the epistemological one. This demarcation has an ethical, professional, and, to a lesser 
degree, legal nature and fixes the boundary between the reponsible use, the irreponsible use, and the abuse of history. Although the ethico-legal demarcation often leads to an epistemological distinction between false and provisionally true knowledge (and this the reason why I shall call one classic type of abuse 'the epistemological type'), it is partly different and broader, as we shall see. It is concerned less with the theories of historians than with the historians themselves, less with truth than with truthfulness. Of historians who are accurate and honest, I shall say that they use history responsibly; of those who are not honest, I shall not say at once that they are irresponsible or dishonest historians (for this is a judgment about persons rather than about their statements), but rather that they either abuse history or use it irresponsibly.

Table 1 further draws a distinction between professionalism and competence: abusive history can be extremely refined and skillful, hence competent, but it is never professional (because it violates the accountability principle). All types of history lie on a continuum ranging from very competent to very incompetent history. Incompetent (or 'bad') history - the product of error, imperfect insight, bias, and lack of training - can be heavily distorting and prejudiced, but it is not irresponsible or abusive as long as it does not transgress the moral boundary of dishonesty or gross negligence. Table 1 also distinguishes harm from risk. I maintain that the abuse of history is always harmful (a point elaborated below) and, in addition, frequently dangerous (as briefly illustrated above).

Responsible scientific history and nonscientific history can also be harmful and dangerous, but for other, mutually exclusive, reasons: nonscientific history because it may supply myths that incite hatred and violence; scientific history because it may destroy cherished myths and exploding taboos, at the risk of unleashing retaliatory violence in the process. If the latter is the case, responsible historians risk being treated as destroyers of reputations or as traitors and being persecuted by governments, individuals, or groups. In these matters, the historical perception of the public is crucial: frequently, audiences are not able to distinguish scientific from nonscientific history and are not willing to accept harsh truths over comfortable errors and lies. 


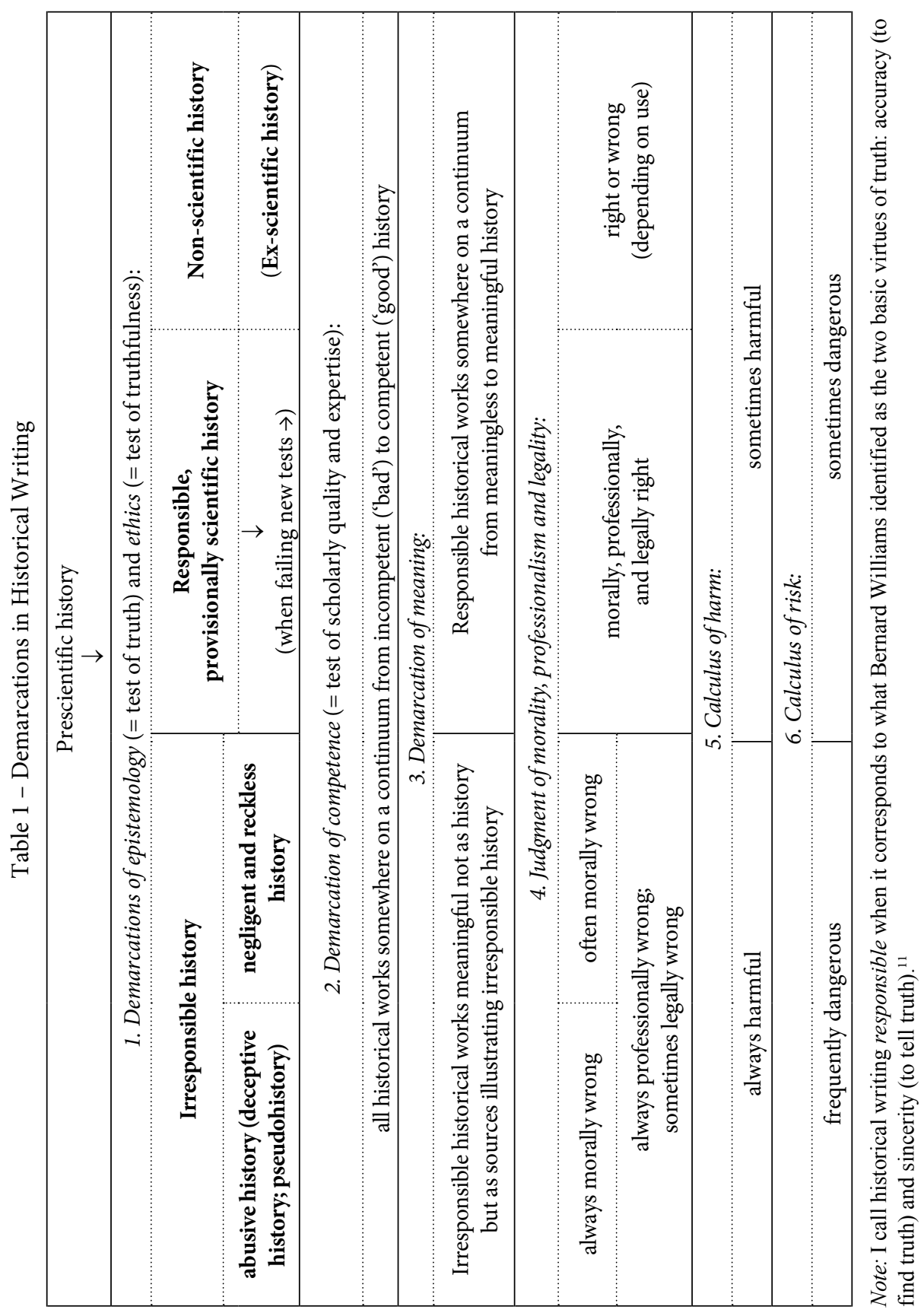




\section{DEFINITIONS}

The irresponsible use of history and the abuse of history are not identical. While the latter is characterized by the lack of integrity, the former is broader and characterized either by the lack of integrity or the lack of care (or both). I propose the following definitions:

The abuse of history is its use with intent to deceive.

The irresponsible use of history is either its deceptive or its negligent use.

All abuse of history is irresponsible history, but not all irresponsible history is an abuse of history. 'Abuse of history' is an expression reserved for the stronger forms of irresponsible history, as is its synonym 'misuse of history.' The essential distinction between the abuse and the irresponsible use of history is located at the level of intention. As this will be explained later in the text, for the moment I shall concentrate solely on the stronger and potentially more problematic definition, that concerning the abuse (or misuse) of history.

Critics could reject my definition of the abuse of history because it harbors no reference to the negative consequences that the abuse entails for other persons. After all, abuse without harm is not very interesting. If this is indeed the case, why not reword the definition as the abuse of history is its use with intent to deceive and resulting in harm to others? With the term 'others,' this consequentialist definition introduces the victims of the abuser. Usually, two classes of victims are distinguished. Direct victims are those who have their health, reputation, income, or opportunities damaged. One may think of the people studied, those alive and (insofar as privacy and reputation are concerned) those deceased, and their relatives; authors whose work is plagiarized or falsified and their publishers; those providing information, assignments, contracts, and funding to the abuser; and all of the customers buying the deceptive product. A second class of victims encompasses those with no immediate interest: the community in which the direct victims lived and all of those misled by the deception, including scholars and experts. Although this alternative definition looks plausible, there are many objections to it.

First of all, the alternative definition would diminish the morally and professionally condemnable nature of deception, that is, of malicious conduct 
as such. ${ }^{12}$ Second, the definition would exclude attempts: the abuse that was not only prepared but also substantially close to completion, but stopped or disclosed before being entirely executed. Some abuses of history can be committed on the spot, whereas others require considerable preparation. While these first two objections regard conduct, further objections focus on the concept of harm itself. In the first place, the alternative does not take into account abusive conduct that could have resulted in harm, but did not because it was unsuccessful. The existence of a risk of harm (inferred from the magnitude, likelihood, and imminence of the harm) is itself harmful. ${ }^{13}$ Second, the actual harm done to other persons is often not immediately and fully known at the time the abuse is committed (and if it is, it is not always accurately assessable in economic terms). In addition, substantial harm can present itself as an indirect effect of the abuse. Third, the alternative definition tends to overlook abuse that profits the abuser, but does not ostensibly harm others. However, if somebody gains an unfair advantage, all of those abiding by legal, professional, and moral rules are harmed proportionally. This third objection thus assumes that abuse always produces harm to other persons.

The final and perhaps most important objection is a radicalization of this thought. The alternative definition neglects the argument - weak in legal, but strong in professional and ethical terms - that the intent to deceive always harms even when it does not result in harm to other persons. This is so because the concept of victim may be said to encompass a hitherto unmentioned third class: historical writing itself. ${ }^{14}$ Arguably, abuses by historians always damage historiography, because historiography is a collective enterprise in which society has an interest. This is all the more so when we deal with professional historians, because society places confidence in their academic and professional qualifications and requires accountability. Abuses threaten that confidence and, therefore, the authority and efficiency of professional historical writing. They engender social costs in terms of the declining credibility of the historical profession and lower the overall quality of the historical discourse. ${ }^{15}$ They stimulate beliefs in historical myths and propaganda or induce amnesia concerning previously known history. The harm done to historical writing is a social harm. When postdictatorial or postconflict societies evolve toward democracy, the harm suffered by historical writing during the preceding dictatorship or conflict gradually comes to light. 
Often, as was the case in postcommunist societies after 1989, history had gained the sad reputation of an unreliable discipline that condoned abuses. Some observers even think that this bad reputation was an important reason for the option of truth commissions to be discarded as a way of dealing with the repressive past in many of these societies. The overall public respect for, and trust in, the historical profession was undermined almost fatally (De Baets, 2002, p.22).

In sum, my last two objections support the view that harm consists of both the negative results of an abuse and that abuse itself. For all these reasons, my definition of the abuse of history stands.

\section{The Importance of a Theory on the Abuse of History}

The discussion above enables me to answer the question of why the abuse of history is wrong. It is always morally wrong because citizens (including citizens who are historians) have the (moral) duty to be honest and, even if there are circumstances where one is not obliged to tell all of the truth, ${ }^{16}$ the intent of not speaking should not be to deceive. In addition, almost always the aim of deception is to acquire an unfair advantage. ${ }^{17}$ The abuse of history is always professionally wrong because, in addition to their moral duties as citizens, professional and academic historians have a duty to apply scholarly and professional standards of care, in particular to search honestly and methodically for the historical truth. Only to the extent that they meet this duty are they granted certain rights, namely academic freedom for themselves and autonomy for the university. Deception, as shown, evades accountability and undermines the trust placed by society in scholarship and teaching. For this reason, abuses of professional historians are worse than those of nonprofessionals. Whereas the responsible use of history - including many forms of responsible selection and omission of facts - is protected by intellectual and academic freedom, the abuse of history is not. And some forms of abuse (for example, excessive secrecy or censorship...) are not even covered by the right to free expression. ${ }^{18}$ Finally, abuse is sometimes legally wrong, namely when it transgresses the law and in particular when there exists a risk of harm to other 
persons (for example, violation of the latter's free expression or infringement of their copyright). ${ }^{19}$

The demarcations and definitions discussed above provide the backbone for identifying the material and mental elements of the conduct of the abuser. Together these elements constitute the evidence for abuse or irresponsible use. Next, an analysis of the motives for the abuse will clarify the explanations that exist for it. And, finally, both evidence and explanation form the infrastructure for the complex process of evaluating the abuse in similar and different historical contexts. The importance of a universally applicable theory on the abuse of history, then, is this: it is a tool to identify, prove, explain, and evaluate the abuses of history, with the ultimate aim of opposing and preventing them.

Evidence of Abuse and Irresponsible Use: Material Elements

In order to prove that a given use of history is indeed an abuse, we need to look into its mental and material elements. The former are related to the mind of the abuser, the latter are not. Material elements comprise the conduct itself (consisting of an act or an omission), the consequences of that conduct, and the spectrum of circumstances (and by extension the context) in which the conduct takes place.

Let us first look at the conduct itself. The irresponsible use and the abuse of history operate at three levels: heuristic, epistemological, and pragmatic. Each level has its specific unit of analysis. At the heuristic level, it is the data perceived as sources or sets of sources (archives). At the epistemological level, it is the data perceived as words or sets of words (statements of fact and opinion, whether or not grouped as theories). At the pragmatic level, it is the data perceived as a whole (the historical work itself) and the use made of that whole by the author and others. When historians collect sources maliciously, they commit heuristic abuse. When they dishonestly change the evidential value of their nonscientific theory in order for it to pass the test-for example, by omitting, trimming, or inventing data, by knowingly presenting nonscientific theories as scientific ones, or by distorting provisionally scientific theories - they commit epistemological abuse. This is the classic form of abuse. 
Usually, this type attempts to attach the respect and trust associated with genuine historical writing to itself. The pragmatic abuse of history occurs when historians lie about their authorship or the status of their work, or when others irresponsibly interfere with it. The result of abuse deserves the name of 'pseudoscientific history,' 'pseudohistory,' or 'bogus history.' ${ }^{20}$ Table 2 presents a typology of heuristic, epistemological, and pragmatic types of conduct, irrespective of their individual importance.

In principle, the typology is valid for all genres of historical sources. Many believe, though, that some historical sources are more amenable to abuse than others. Source editions (including digital source editions), genealogies, biographies, memoirs, obituaries, chronicles, chronologies, annals, maps, photographs, bibliographies, historical dictionaries, encyclopedias, statistics, indexes, archive catalogs, history textbooks and oral histories have all been mentioned as sources especially vulnerable to abuse. ${ }^{21}$

As for the different historical periods, Donald Cameron Watt noted in 1985:

The study of contemporary history has scarcely been undertaken at all by serious historians because of the potential for government manipulation for political purposes. Indeed there has been a strong bias against contemporary history in academic circles because of its frequent misuse. ${ }^{22}$

Times have since changed - contemporary history is studied more than any other period - but Watt's remark retains its historical value.

Table 2 - Typology of Abuses and Irresponsible Uses of History

Upstream of the historian's work

- heuristic level (archives) -

Heritage and written and unwritten archives

- Intentionally damage and destroy heritage; loot heritage; illegally trade in objects of heritage.

- Archival cleansing: Illegally destroy, remove, conceal archives; neglect archives. $^{23}$

- Maintain excessive secrecy or illegal nondisclosure of archives; illegally prohibit access to archives.

- Intimidate and eliminate producers, owners, and custodians of archives. 


\section{During the historian's work \\ - heuristic level (source collection) -}

Irresponsible destruction of sources from others

Irresponsible collection of sources from others

- Deceive or blackmail informants and witnesses.

- Accept money from, or give money to, informants and witnesses beyond normal costs.

- Theft: Steal work of others.

- Piracy: Illegally reproduce or distribute copyrighted work of others (except selections used in research and teaching that are compatible with fair use if source and author are indicated).

Irresponsible use of sources from others

- Plagiarism: Deliberately present ideas and words expressed originally by others as own work (that is, without accurate acknowledgment of the source).

- Falsification: Falsify work of others, for example, by deliberately changing colophons or data about origin or property.

- Bibliography, notes: Supplement own bibliography or notes with entirely unread works.

Irresponsible use of sources in general

- Monopolize or keep secret information that should be publicly accessible.

Fabrication of own sources (falsification ex-nihilo)

- Invent informants and witnesses.

- Fabricate sources (pseudo-originals).

- Invent provenance of sources (may include falsifying catalogs, certificates, signatures, etc.)

- Invent trustworthiness of sources, for example, by presenting them as (really or supposedly) lost sources, long searched for, or a translation thereof, and suddenly discovered.

- Supplement own bibliography or notes with fabricated works.

\section{During the historian's work - epistemological level (data description and analysis) -}

Official and private providers of data, assignments, contracts, funding

- Impose nonscientific provider-favorable conditions on research mandate.

Description of raw and processed data ${ }^{24}$

- Use invented sources and their 'data.'

- Irresponsibly select and omit data. ${ }^{25}$ 
- Knowingly deny or minimize corroborated data.

- Misrepresent and falsify data.

- Maliciously present data without any historical context or within a wrong historical context.

- Irresponsibly or defamatorily disclose privacy-and reputation-sensitive data.

- Disclose confidential or embargoed information without permission.

- Falsely attribute information or ideas of others to oneself.

- Falsely attribute information or ideas to others.

- Bibliography, notes: omit important read works or purposely annotate them inaccurately.

Data analysis

- Logic:

Purposely misapply logic or research methods and techniques.

Purposely weigh evidence incorrectly by omitting, ignoring, minimizing contradicting evidence, and exaggerating supporting evidence.

- Rhetoric:

Organize and present arguments in a misleading or deliberately obscure narrative structure. ${ }^{26}$

- Interpretation:

Purposely conclude incorrectly.

Recklessly disregard implicit moral judgments.

Make explicit moral judgments negligently or maliciously.

\section{During the historian's work \\ - pragmatic level (publication of work) -}

\section{Autobiographical lies}

- Forgery: Maliciously attributing original own work:

1) to other real (contemporary or historical) authors, or

2) to fictitious or anonymous authors (except pseudonymity or anonymity, either disclosed to the publisher or leaving no doubt as to the author's identity).

- Attribute - after piracy - work of others to third parties or to oneself.

- Misrepresent own curriculum vitae (origin, identity, education, profession, expertise...).

Lies about the work (manuscript or publication)

- Purposely draft incorrect preliminary synopsis or abstract. 
- Deliberately indicate incorrectly manuscript status in the publication process.

- Submit manuscript simultaneously to several publishers without informing them of this.

- Lack of proper acknowledgment for important or substantial inspiration or help.

- Lie or maintain silence about official and private providers of data, assignments, contracts, funding, and about conditions imposed by them.

- Purposely remain silent about one's perspective or commitment, or about research modalities when the latter are relevant.

- Wrongfully suggest independence, impartiality or prestige.

- Lie about period of research and time of publication.

- Lie about joint authorship or about contributions of coauthors (mention as authors of persons who did not collaborate; omission as authors of persons who did collaborate.)

- Falsify contracts.

Lack of accountability

- Active resistance against legitimate control of own data or work by others.

\section{Downstream of the historian's work}

- pragmatic level (reception of work) -

\section{Censors}

- Delete or change authorship without authorial consent.

- Pre- or postcensor text with or without authorial consent.

- Interfere improperly with the content of a teaching course.

Official and private providers of data, assignments, contracts, funding

- Pressure to adapt manuscript so as to embellish, or to conceal, unwelcome messages.

Editors, publishers, and their staff

- Abuse editorial control.

- Steal, falsify, irresponsibly omit data from manuscripts or fabricate them.

- Reject work otherwise approved in order to harm careers or favor rivals.

- Deliberately brief authors incorrectly about approval criteria or publication process.

- Delay publication of approved manuscript for improper purposes. 
Peer reviewers of manuscripts, books, textbooks, courses (in the context of publication, employment, tenure, promotion, grants, congresses, and prizes)

- Keep silent about either conflict or harmony of interests between reviewer and reviewed.

- Abstain from reading the entire text; a priori judge favorably or unfavorably; invent judgment.

- Invent data or misrepresent data from reviewed text.

- Lie about authorship of reviews.

- Commit piracy or plagiarism of data submitted by the reviewed.

Beneficiaries of the historical work (mass media, audience, leadership)

- Invent, plagiarize, intentionally distort data.

Sources include American Historical Association, Berne Convention, Bernheim, Bloch, Broad \& Wade, Brugioni, Chubin \& Hackett, Eco, Fischer, Grafton, Haywood, Jaubert, Kurz, LaFollette, Langlois \& Seignobos, Ouy, Pradel, and Vansina. ${ }^{27}$

Table 2 immediately lays bare the simple fact that many parties are involved in the activity of historical writing. To the extent that this activity becomes more dependent on governments (for example, for salaries or archival infrastructure) or private concerns (for example, of publishers), the interests at stake in history writing multiply, as do the numbers of those willing to participate in its supervision - and as does the risk of abuse.

Most of the time, the conduct constituting the abuse has certain consequences - events or states of affairs that can reasonably be inferred from that conduct. The discussion on the definition of abuse made it clear that, in particular, harmful consequences are of special interest. The abuse is also embedded in specific circumstances, which can be legal, factual, or both. Legal circumstances occur when the law prohibits the abusive conduct. Factual circumstances relate to the modalities of abuse, for example, that the abuser was a student. Some factual circumstances are more conducive to abuse than others, for example, heavy moral or material pressure from outside, blackmail, the weight of schedules, and workload. A good example of a factual circumstance deeply influencing abusive conduct is censorship. Censorship is abuse in which the content or exchange of historical facts or opinions is systematically controlled (often by deliberate suppression) by others (usually the government, but also colleagues, sponsors, source providers, or pressure groups). 
The context of the historian's conduct is an extension of the circumstances. It is obviously relevant to know whether the abuse was committed, for instance, during a war or under a dictatorship, or in the twelfth or the twentieth century. One of the most important context variables is whether the abuser acted alone or was part of a larger group, and whether the activity of that larger group - most probably the government or an organism linked to it was an exception or part of a widespread or systematic pattern. I recognize, however, that my theory is better suited to analyze situations of individual abuse than situations in which a large group of leading historians abuses history for a 'greater' cause.

\section{Evidence of Abuse and Irresponsible Use: Mental Elements}

In the description of material elements, it is almost impossible to avoid qualifications of intent (like 'purposely,' 'deceptively,' 'irresponsibly,' 'carelessly,' 'in good faith,' or 'malafide'). Strictly speaking, intent is dual: it consists of the desire that a consequence occurs (the volitional aspect) and of the foreseeability of that consequence (the cognitive aspect). Depending on the varying presence of these two components, usually four gradations of intent are distinguished. ${ }^{28}$ In the stronger gradations, the conduct is malicious; in addition, the harm inflicted is more under the control of the abuser than in the weaker gradations. Direct intent means that the consequence of the abusive conduct is certain or probable, foreseeable, and desired. We speak of indirect intent when the consequence of the abusive conduct is certain or probable, foreseeable, and accepted, although not especially desired. Whereas the first two degrees of intent are called 'specific intent' because they express determination and purposiveness, the third and fourth degrees are sometimes taken together as 'general intent.' The third form, then, is recklessness: the consequence is not certain but still possible, foreseeable but not desired, and the considerable risk of its occurrence is taken. A variant of this is called 'willful blindness.' The fourth form is negligence (or carelessness): the consequence is possible, foreseeable, and not desired, but the risk of its occurrence is neglected. ${ }^{29}$ Recklessness is sometimes called 'willful negligence.'

Intent lies between motive and purpose. On the one hand, it is associated with, but clearly different from, the motive lying behind the intent (see 
below). On the other hand, it is closely connected with purpose, but only in the stronger gradations where the consequences of the conduct are certain (or highly probable), and desired or accepted. The four degrees show that the meaning of 'intent' in 'intent to deceive' is far larger than the meaning of 'intention' as commonly understood. Hyman Gross, who developed a theory of criminal justice, made this clear as follows: "Acting intentionally is often not a matter of fulfilling an intention." (Gross, 1979, p.94). Responsibility for committing an abuse and displaying 'intent to deceive,' then, is dependent on the degree of control by the abuser.

This enables us to explain and refine the distinction, already mentioned, between abusive and irresponsible history: abusive history is done purposely or knowingly; irresponsible history is done recklessly or negligently. To use the same concept for extremes, such as historical propaganda that incites genocide on the one hand, and negligent micro-abuses on the other, although theoretically defensible because they are covered by the same roof (intent), would be seriously confusing. All reckless and much of the negligent conduct is sufficiently blameworthy to fall within the two lowest degrees of our definition of intent, but to differentiate it from the stronger abuses, I shall call it 'irresponsible use.'

Evidence of Abuse and Irresponsible Use: Material and Mental Elements

Judges will often rule against historians accused of abuse on the basis of proof for the latter's premeditation or their deviation of generally accepted standards of care that prudent historians should observe. The search for evidence, in this case for the material elements of abuse and irresponsible use, is also the daily business of historians. Through the ages, they have developed rules of historical criticism to verify the authenticity of sources with respect to their form and content. ${ }^{30}$ Hence, they routinely search for internal and external inconsistencies and anachronisms in sources.

Proof of the mental element is less obvious. Of course, some acts automatically imply malicious intent (mala in se), for example, stealing a manuscript. Usually, however, intent is inferred from the relevant material elements (conduct, circumstances, consequences), and, to a lesser degree, from 
abuser confessions. Judges, for example, may infer it from the choice of language, the one-sided nature of statements, or the precise moment of their utterance. ${ }^{31}$ It is not easy to base proof of intent to deceive on convincing, let alone compelling, evidence. This means that the demarcations (1) between the abuses of history and the irresponsible uses of history, and (2) between the irresponsible and responsible uses of history, are not always clear, especially in two areas: the difference between deliberate omission, reckless omission, and negligent omission of data, and the difference between recklessness and negligence. As far as the latter area is concerned, even if there is a clear difference between the reckless disregard of the truth and a simple error, the boundary between blameworthy negligence and simple negligence can be thin. There are gray areas and degrees of appreciation between error, exaggeration, and lie. ${ }^{32}$

\section{Explanation of Abuse and IrResponsible UsE}

After the abuse of history is defined and described, the theory should now focus on problems of explanation and on those of motivation in particular. Motives are sometimes called 'ulterior intent.' (Gross, 1979, p.103-113). Black's Law Dictionary explains: "While motive is the inducement to do some act, intent is the mental ... determination to do it." ${ }^{33}$

From the accumulated knowledge about motives, two assumptions are important for our theory. First, a given conduct can have one motive, but can have also none or several. Second, actors are often barely conscious of their motives, and, when asked to formulate them, they do not necessarily provide clear answers or real motives. Rationalization of motives is a frequent practice. Almost always, writing history rests upon a combination of motives that spring from personal or collective needs, emotions, and interests (see Fischer, 1970, p.213-215). In Table 3, I distinguish two main groups: scientific (or intrinsic) motives and nonscientific (or instrumental, consequentialist) motives. These motives partially overlap. Nonscientific motives are very common and sometimes overriding. They are acceptable to the extent that they remain compatible with intrinsic motives.

It is time for an example. Historians can (and many do) write history to discover the historical truth (scientific motive), satisfy their curiosity 
(nonscientific, recreational motive), tell a story (nonscientific, literary motive), and earn money (nonscientific, economic motive). Historians who study the past of their national state and want to show how a certain royal house came to power have a legitimate motive. If, however, they intend to conceal criticism of the predecessors of the present king out of monarchism or in order to guarantee future employment as the palace's archivist and court historian, their political, professional, and ideological motives prepare the ground for malicious intent. Again, the point here is that nonscientific motives do not necessarily lead to nonscientific history, though in certain circumstances they may ignite negligence or malicious intent. Only two rules of thumb can be given. First, the risk of abuse is enhanced when scientific motives are less central. Second, among possible combinations of nonscientific motives, some tend to focus exclusively or mainly on favoring oneself or favoring or excluding others and, therefore, are the most prone to induce malicious intent. ${ }^{34}$

Table 3 - Motives for Historical Writing

\section{Scientific or intrinsic motives}

Primary-scientific (history-related)

Search for and disclose true historical knowledge.

Secondary-scientific (history- and memory-related)

Search for and disclose true historical knowledge as a struggle against oblivion, historical taboos, or denial of the past.

\section{Nonscientific or instrumental motives}

\section{Educational}

Acquire historical awareness and orientation in time.

Acquire insight into processes and structures.

Moral

Document good and bad conduct as examples (historia magistra vitae). Apportion praise and blame.

Prevent repetition of past crimes and conflicts. 


\section{Didactic}

Learn lessons from the past.

\section{Cultural}

Stimulate cultural knowledge.

Conform to dominant or minority cultural group.

\section{Philosophical}

Enhance self-understanding through orientation in time.

Clarify human existence and endow it with meaning.

Explain identity (origin, continuity, and destiny) of individuals and groups.

Participate in the story of humanity.

Predict the future.

\section{Religious}

Develop an acceptable religious version of the past.

Defend a religious doctrine.

\section{Metaphysical}

Pay a debt to the ancestors.

Pay tribute to the heroes and victims of the past.

Racial, ethnic

Demonstrate racial or ethnic superiority, inferiority, or equality.

Conform to dominant or minority ethnic or racial group.

\section{Therapeutic}

Seek consolation and courage.

Heal old wounds and promote postconflict reconciliation.

\section{Recreational}

Seek pastime and amusement.

Satisfy curiosity.

\section{Literary}

Tell stories.

Esthetic, artistic

Create beauty and atmosphere. 
Psychological

Regarding oneself:

Clarify genealogy and identity.

Satisfy nostalgia and escapism.

Feel oneself attracted to the strange and the old.

Seek recognition and fame, including posthumous recognition and fame.

Project aspirations into the past.

Leave a legacy.

Regarding others:

Convince skeptics of own viewpoint.

Display sense of mission (unique insight into the truth).

Show admiration, loyalty, chauvinism, idealism.

Satisfy resentment (envy, hatred, revenge); settle scores.

Economic, commercial

Earn income, subsidies, profit.

Professional

Realize professional ambition, reputation, prestige, career advantage, power.

Ideological, political, social

Acquire group spirit.

Determine group identity and origins.

Construct social cohesion and identity.

Build ethnic groups, nations.

Build institutions (states, sub- and supranational entities).

Contribute to reparation of historical injustice, to peace, reconciliation, tolerance, democracy.

Create acceptable ideological and political versions of the past.

Legitimize ideologies, practices, traditions, institutions, policies (including status quo, territorial expansion, and human rights violations). 
Legal

Historians writing as or on behalf of:

citizens: Prove claims of genealogy, reputation, law, privilege, profession, property.

victims: Prove crimes, guilt, claims for reparation of

historical injustice.

perpetrators: Prove innocence; seek rehabilitation.

judges: Judge guilt and innocence.

Sources include Bernheim, Bloch, Feder, Gallie, Grafton, Haywood, Karlsson, Kurz, Langlois \& Seignobos, and Vansina. ${ }^{35}$

Table 3 further demonstrates that the abuse of history does not always mean the political abuse of history. Certainly, political motives are powerful; nonpolitical motives often appear to possess a political background or dimension; and, governments are frequently the ultimate cause of the most serious forms of abuse of history. But the abuse of history springs not only from political sources. ${ }^{36}$

Motives provide an answer to the question: why do historians use history with the intent to deceive? They are important to explain and evaluate the abuse, including to determine sanctions, but, in contrast to intent, they do not play a role of significance in determining whether a given conduct is an abuse. Historically, many abusers acted with noble or acceptable motives. Noble or acceptable motives, however, do not make the abuse less abusive; what matters most is the intent to deceive. ${ }^{37}$ Finally, it should be remarked that it would be a mistake to think that we have explained the abuse of history completely once we have identified the motives of the abusers. This is necessary, but not sufficient. The analysis of the material elements must also play a considerable part in any attempt at clarification.

\section{The InTRINSIC IMport ANCE of Abuses}

The rest of the theory is a commentary on the question of how to evaluate abuses and how to handle them. Not all abuses of history - let me repeat this point - have the same weight. Judging the importance of different types 
of abuse and comparing them are the first elements of a broad evaluation procedure. Unfortunately, this is a vexing exercise because the application of evaluative principles sometimes leads to contradictory results. I will demonstrate this now.

The first evaluative principle is related to the degree to which the abuse makes testing it either possible or impossible: traceability. This principle prescribes that, under conditions of an equal mental element, abuses that make data (sources, statements, and works) untraceable are more harmful than others. This is so because the stronger the untraceability, the harder it is to recognize and measure the abuse and its harm. The logic of the principle implies that heuristic abuse is worse than epistemological and pragmatic abuse, because manipulating sources is often harder to trace and less reparable than manipulating statements or historical works. At the heuristic level itself, it means that abuses involving unique sources (e.g., diaries) are worse than those involving nonunique sources, and that abuses committed after monopolistic access to sources are worse than those committed after free access to them. ${ }^{38}$ On this principle, destruction is worse than falsification, and falsification worse than invention.

A similar principle is refutability. On this view, under conditions of an equal mental element, abuses are more harmful than others when they make refutation impossible. At the epistemological level, this principle suggests that abuses of data description are worse than those of data analysis. This means that, if we divide historical statements into (descriptive) statements of fact and (analytic) statements of opinion, the distortion of facts is worse than the distortion of opinions. ${ }^{39}$ The rationale behind this is that if facts are distorted, it is impossible to check the plausibility of opinions based upon them, whereas if opinions are distorted, it remains possible to formulate alternative opinions on the basis of facts that are accurately described. Some critics of this 'fact oriented' version of the principle may reply that facts that are distorted must be important and that if they are important, they are known by several people who can rectify the factual allegations of the abuser. In its absolute form, this argument seems to invest too much responsibility in experts and too much confidence in the self-healing powers of historiography. Other critics say that the 'fact oriented' version of the principle is not valid, because a 
distorted overall historical opinion (or representation) in a historical work is worse than the distortion of singular facts. It is, they say, precisely this overall representation rather than particular facts that stick in the minds of people. This is an important objection and if it is correct, the principle is useless for the distinction between facts and opinions.

This does not mean, however, that the refutability principle cannot serve as an indicator for other important problems. For example, at the level of data description, it suggests that irresponsible omission of factual data (for example, by prior restraint) is worse than falsifying or inventing them, because omission renders refutation more difficult (similar to the destruction of sources under the traceability principle). Andrus Pork contended the opposite. He writes:

Are there any substantial moral differences between using 'direct lie' [that is, falsification in my terms, $a d b$ ] and 'blank pages' [that is, omission in my terms, $a d b]$ methods? Although it is clearly a choice between two evils, it seems to be that from the point of view of most historians' intuitive ethical understanding, the 'blank pages' method is morally more acceptable. After all, the selection of facts for a narrative is inevitable. (Pork, 1990, p.327)

Obviously, selection of facts is not only inevitable, but also obligatory for historians, let alone history textbook authors. I believe that Pork, however, misses the main point, namely that a selection stemming from a particular perspective containing an often inevitable cognitive bias is different from an irresponsible or abusive selection that is evitable.

There is another evaluative principle that works in the opposite direction of the traceability and refutability principles. This principle prescribes that abuses significantly diminishing the overall trust in historical writing and its practitioners are more harmful than others. On this principle, falsification and fabrication arouse more distrust than omission precisely because they are generally more visible and traceable. Application of the trust principle and application of the traceability or refutability principle thus lead to opposite results. From this discussion, I conclude that principles for determining the importance of abuses as such form a necessary but unsatisfactory part of the 
evaluative process, because, although certainly enlightening, they do not cumulatively support each other.

\section{The Importance of Abuses Relative to Textual Context}

The importance of epistemological abuses can also be gauged by evaluating them in their textual context. The question here is this: how to determine whether, in a given text $(T)$ consisting of $n$ statements $(S)$, the presence of a single statement $\mathrm{Sa}$ (a statement shown maliciously to be false or fabricated) justifies an overall judgment of 'abuse of history' in relation to T? Suppose $T$ consists of one hundred true $S$ and only one $S a$, can $T$ in its entirety be called an abuse of history or not? Is the author an abuser of history or not? To complicate matters: one should consider that skillful and subtle abusers do not blatantly falsify the historical record, but leave intact as much of the past as they can and only alter key passages so as not to arouse suspicion about their purposes (De Baets, 2002, p.17). The answer to the question will depend on the importance of the abusive statement, $S a$, within the entire argument, $T$.

\section{The Importance of Abuses Relative to Frequency}

There is another problem, closely connected to the demarcation issue: the frequency of irresponsible uses of history, on the one hand, and abuses, on the other, may reverse their relative importance. Indeed, the lighter forms of irresponsible use occur far more frequently than the worst abuses. In addition, some of the lighter forms are barely visible and detectable. Furthermore, a continuously high frequency of lighter forms affects the work climate; it makes the environment more condoning and the work habitus sloppier. If that is the case, the lighter forms tend to involve more people. And once condoned, they may have a slippery-slope effect and make the occurrence of grosser abuses more likely. In addition, this mechanism is transsystemic, that is, active in democratic as well as nondemocratic systems.

Seen from this angle, the lighter forms of irresponsible use are the most important of all of the questionable uses, and the more serious forms of abuse, because of their lower frequency, are less important. This conclusion implies 
that negligence - as the mental form that lighter forms of irresponsible use adopt - is far less innocent than its low degree of intent suggests. On the other side, this conclusion creates a possibility for effective remedy, because it demands structural attention for preventive strategies that focus on the many lighter forms of irresponsible conduct.

\section{JUSTIFICATIONS AND WRONGDOING}

The lesson to be learned from the preceding discussion is that judging abuses should be done with a broader evaluative horizon that includes the parties involved: victims and abusers. The three categories of victims were already identified at the outset of our theory. When we turn our attention to the abusers, a first necessary step is to consider grounds for justification - reasons showing that an alleged abuse was not an abuse. Distortions of history effectuated in good faith are such justifications. They are not abuses, for there is no intent to maliciously deceive, and they are not irresponsible uses, for there is no blameworthy negligence. Examples at the heuristic level include the restoration under scientific conditions of objects and manuscripts (such as facsimiles, transcriptions, and translations) and the bona fide reproduction of lost or damaged originals. At the epistemological level, one should think of scholarly corrections, revisions, and interpolations. Stylistic exercises of imitation and homage, when openly acknowledged, belong to this category. At the pragmatic level, voluntarily relinquishing the economic profits of copyright is such an instance. ${ }^{40}$

Many other bona fide deformations are not mentioned here, as they are relatively rare in professional historical writing, for instance, parodies or other techniques of historical novels with their large margins of appreciation of historical reality. These deformations are often deceptive, but they are not abusive if their authors do not intend to keep secret the possible deception at all costs. Therefore, the deception cannot be said to be malicious. And some liberty in dealing with historical facts is a normal feature of these literary genres governed by different criteria and expectations.

Can other grounds for justification be invoked as a defense? Can historians argue that they did not know that what they were doing was abusive 
(ignorance) or that they committed an abuse unintentionally (mistake)? Since we are talking here about professional historians, trained to act consciously as experts and to be acutely aware of the limits of their knowledge, ignorance is often a poor defense. Judges usually react with impatience when confronted with false statements of fact due to ignorance. The other defense, mistake, is more serious. No historian is perfect; like others, they commit errors or forget or underestimate relevant facts and arguments in favor or against their theory. ${ }^{41}$ These are cases of simple, inadvertent negligence. But what if the number or nature of the mistakes is 'unreasonable'? What if negligence takes place on a large scale (brought about by laziness, haste, incompetence, credulity, self-deception, bias)? Large-scale negligence by academic historians who are supposed to act with accuracy results in bad history transgressing the boundary of blameworthy negligence (the lowest degree of intent and of blame). In short, it is at least an irresponsible use. ${ }^{42}$ "Accuracy is a duty, not a virtue." ${ }^{43}$

If no justifications can be invoked, the question of wrongdoing arises. Any accusation of wrongdoing should be substantiated; allegations alone are not sufficient. False complaints should lead to rehabilitating the accused and sanctioning the complainant. Assuming that the complaint is accepted, guarantees for fair treatment and due process apply. These include presumption of innocence of the accused, burden of proof for the complainants, written case files with the right to reply, defense opportunity, and appeal. Once the evidence for the abuse is accepted, general principles for apportioning blame and guilt are applicable. First, the higher the degree of intent, the larger the wrongdoing will be. Also, the more the harm was desired, foreseeable, imminent, or, when inflicted, serious, the larger the wrongdoing will be. In particular, harm resulting from crimes attributable to the abuse of history - for example, when historical propaganda directly and publicly incites hatred, discrimination, and violence, or the commission of genocide ${ }^{44}$ - maximizes wrongdoing. Second, abusers, as well as those aiding and abetting them, are responsible, but the former is usually more so than the latter. Special attention should be given, however, to the role of the masterminds who planned and organized the abuse and of the censors or providers of contracts and budgets who exerted pressure and, by so doing, had a dominant influence on the abusive conduct. 


\section{Excuses AND Pseudo-Excuses}

The next problem is how to sanction the abuse once it is determined. Sanctions are excluded entirely or partially if valid excuses exist. In two situations, these excuses are responsibility-denying. To begin with, there is the situation, just mentioned, of coercion: in such circumstances, the abuse was sometimes inevitable because it took place under severe pressure. For example, historians were forced to commit abuses on orders of third parties, such as censors, and refusal of compliance signified a substantial threat to their or their family's life or safety or to their career and income prospects (as is rather common under dictatorships). The extent to which autonomy was lacking determines the excusability. The second excuse is mental abnormality, either chronic or episodic: the abuser suffered from a mental illness or from intoxication (furiosus furore solum punitur). There is also a harm-denying excuse: the abuse was so small that punishing its abuser would do more harm than the abuse itself (de minimis non curat lex). One must think here of cases where the abusers are history students at a stage in their education at which they were not yet fully aware of professional ethics or did not yet master fully the techniques of historical research. Precise information in history courses can play a preventive role and reduce this comparatively large group of cases substantially.

Statements of abusers about their motives and intentions, although valuable in many respects, are not always transparent, logical, or true. Pseudoexcuses are of two types. Some are dishonest justifications or forms of selfdeception - excuses which may be valid as such but which are invoked improperly in the case at hand. Many abusers typically use defense pleas, such as: "I was distracted, sloppy, stressed, playful, temporarily out of control; my abuse was inadvertent; it was a jest," while, in fact, this was not the case. Such dubious assertions, of course, complicate the task of providing a substantial evidential base for the abuse. Other excuses are manifestly ill-founded most of the time. Table 4 offers a tentative list of the second type. 
Table 4 - Pseudo-Excuses for Abusing History

\begin{tabular}{|c|c|c|}
\hline Abusers are: & and typically they say: & $\begin{array}{l}\text { Their defense } \\
\text { regards: }\end{array}$ \\
\hline $\begin{array}{l}\text { exceptional } \\
\text { mediating }\end{array}$ & $\begin{array}{l}\text { I have a special mission exempted from normal } \\
\text { procedures. } \\
\text { I am guided by irresistible supernatural forces. }\end{array}$ & their person \\
\hline $\begin{array}{l}\text { good } \\
\text { compulsive }\end{array}$ & $\begin{array}{l}\text { I have a good character. } \\
\text { I could not help it. }\end{array}$ & their character \\
\hline cryptomnesiac & $\begin{array}{l}\text { I unconsciously borrowed information from } \\
\text { others. }\end{array}$ & their memory \\
\hline $\begin{array}{l}\text { clean } \\
\text { noble }\end{array}$ & $\begin{array}{l}\text { I had no motive to commit abuse. } \\
\text { I had a noble motive } \\
\qquad \text { (pia fraus). }\end{array}$ & their motive \\
\hline ignorant & $\begin{array}{l}\text { I did not know that it was an abuse } \\
\text { (ignorantia legis non excusat). }\end{array}$ & $\begin{array}{l}\text { their } \\
\text { knowledge }\end{array}$ \\
\hline $\begin{array}{l}\text { reluctant } \\
\text { euphemistic } \\
\text { occasional } \\
\text { respectful } \\
\text { denying } \\
\text { futile } \\
\text { defensive }\end{array}$ & $\begin{array}{l}\text { It does not need examination. } \\
\text { It deserves another name than 'abuse.' } \\
\text { It was an accident. } \\
\text { It was a tribute. } \\
\text { It was no abuse but responsible use. } \\
\text { It was insignificant compared to my complete } \\
\text { works. } \\
\text { It prevented grosser abuses from being } \\
\text { committed (lesser evil). }\end{array}$ & their conduct \\
\hline $\begin{array}{l}\text { misunderstood } \\
\text { victimized } \\
\text { innocent } \\
\text { accusing } \\
\text { ordinary } \\
\text { better }\end{array}$ & $\begin{array}{l}\text { Others did not appreciate my work; therefore, I } \\
\text { took revenge. } \\
\text { Others abused my work also. } \\
\text { Others committed the abuse, not me. } \\
\text { Others now exposing me produced abusive } \\
\text { work themselves (first stone). } \\
\text { Others committed abuses also ( } t u \text { quoque). } \\
\text { Others committed worse abuses. }\end{array}$ & others \\
\hline democratic & Everybody commits abuse. & all \\
\hline
\end{tabular}




\section{Mitigating And Aggravating Circumstances}

In addition to (legitimate) excuses, there may be mitigating factors at work after the abuse occurred. The first of these is the regret expressed by abusers either implicitly when they repent and abandon attempts to abuse, or explicitly when, once the abuse has occurred, they cooperate, confess, publicly apologize, and / or amend the harm inflicted. The second is an estimation of the abusers' new situation, in particular, whether the sanction imposed would lead to unreasonably grave consequences for them. Finally, there are two time-related factors. Limitations, statutory or other, may apply when the disclosure of the abuse occurs several years or decades after the facts and sanctions become superfluous when the abuser is deceased.

Three responsibility-related factors may have aggravating effects. The first factor occurs when the abuser is a professional historian. The second is the case of the mastermind manipulating others to commit abuses. The final factor is repetition of the offense leading to serial abuse or serial irresponsible use.

\section{SANCTIONS}

Sanctions for abuses should be applied wisely and with restraint, and should pursue four goals: to force or stimulate abusers to change their conduct (if, at least, the abuser's identity is known); to deter others from imitating them; to repair harm done to victims; and, to encourage all historians to take preventive measures and to help preserve the integrity of historiography. The principles guiding the operation are well-known. Sanctions should not cause more harm than the abuse did. They should take into account abuser motives, excuses, and mitigating and aggravating factors. They should be proportional to the degree of intent, to the risk of harm, and to the harm effectively inflicted. The burden of reparation should be distributed equitably over various abusers and the benefits of reparation distributed equitably over different victims. Sanctions should also apply to attempts to abuse, but be less strict than those applied for completed abuses: attempts may be counted as abuse only if it can be shown that the intent to deceive was clearly present. Finally, sanctions should be limited in time and offer, if possible, some perspective beyond them. 
In practice, these principles are not always applied strictly. There are three types of sanctions: symbolic, professional, and legal. The first type is the most frequent. Symbolic sanctions are imposed by victims or third parties. A first scenario is that the identity of the abusers is known to their victims or to third parties, but not to the public. The effect of this on the abusers is unpredictable: their loss of reputation may encourage them either to express regret or to commit further, more subtle, abuse. Victims may find selective disclosure frustrating or, alternatively, see it as an instrument to exert pressure on the abuser and demand reparation. As for the public ignorant of the abuse, it may still be harmed by it. Confidential symbolic sanctions, often imposed without a fair and full examination of the facts, serve two purposes: satisfaction for the victim through private confession, excuse, or reparation by the abuser, and, consequently, a clean slate for the latter. They often take the form of a friendly settlement backed up with the threat of exposure. Public symbolic sanctions may entail satisfaction for the victims and make the public aware of the abuse and the abuser. Typically, they take the shape of an investigation culminating in the disclosure and refutation of the abuse in a journal or on the Internet, or of a public discussion with the abuser. This scenario is often accompanied by a request to the abuser for public rectification and apology.

Professional sanctions are imposed by an association of professional historians or the home academic institution of the abuser. They range from withdrawal of the malicious publication and a requirement for rectification in future writings, to reprimands or suspension for shorter or longer terms. Legal punishment is imposed by the law or by a judge. It consists of the seizure of copyright infringing copies of a work, injunctions restraining publications, and demands for rectification in the press, in future editions of a book, or in a future issue of the journal where the problematic text first appeared. Other judicial measures include penalties and compensatory payment for damages, and criminal prosecution and imprisonment of the abusers, their superiors, and accomplices.

Almost all of the sanctions listed above are controversial among professional historians. Some are even strongly reminiscent of the darker periods in which responsible historians, not abusers of history, were forced to publicly recant their deeds or works. This is even more so the case with stronger categories of sanctions than the ones listed above. Measures such as stripping 
abusing historians of their doctoral degrees or credentials, refusal of promotion, demotion, dismissal, early retirement, blacklisting, and so on, all echo reprisals against honest historians under dictatorships. All of this results in a dilemma: on the one hand, no one wants abuses of history or large-scale irresponsible uses of history to go unpunished, especially because indulgence toward the "agents of oblivion, the shredders of documents, the assassins of memory, the revisers of encyclopedias, the conspirators of silence" 45 invites repetition and, on the other hand, almost any type of sanction and almost any adjudication procedure seem to possess awkward echoes of past unjustified repression of historians and they meet, therefore, with hesitation or resistance. This dilemma is what I call the trap of the just judges.

\section{Prevention}

Abuses can also be opposed preventively on four levels at least. Prevention of abuse is fostered through the formation of a careful and honest work habit in the first place, especially by acknowledging intellectual debts in notes and literature and by clearly distinguishing quotation and paraphrasing.

A second level is the furthering of a process of awareness through the explicit teaching of students about ethical questions for historians, including teaching about past abuses of history (De Baets, 2009, chap. 6). At the same time, it is important to fight incredulity in many scholarly circles. Many clichés circulate: "I do not know of any affairs of abuse, therefore their occurrence is low; if they occur, I would know; there were more abuses in the past than now; they occur, but not here; alluding to abuse tarnishes the reputation of our department." Clichés such as these hamper vigilance. The third level is the level of institutional safeguards. The temptation of abuse decreases where academic freedom and institutional autonomy are respected; the selection of, access to, and disclosure of information are well-regulated; a critical and objective method is taught; and a climate of impartial peer review and free and pluralist debate about the past are established.

The fourth level is standard setting, through the development of norms in professional codes of ethics. Such codes should clearly state that all historians have a responsibility to oppose abuse. At the global level, the International 
Committee of Historical Sciences is the profession's umbrella organization. In 1926, when it was "created in order to promote the historical sciences through international cooperation," the Committee drafted a Constitution, Article 1 of which contained the Committee's purpose. ${ }^{46}$ To that Article 1, a sentence about the rights and responsibilities of historians was added in 1992. And in 2005, the General Assembly of the Committee unanimously amended Article 1 again by adding the clause that "it is opposed to the misuse of history"; in French: “il s'oppose à l'usage abusif de l'histoire." The precarious situation of historical writing under the Bharatiya Janata Party that ruled India from 1998 to 2004 had been the immediate cause for inserting this clause. ${ }^{47}$ The move was utterly important in that finally, a recognized universal body of historians formally perceived the abuse of history, despite the variety of situations it covers, as a concept in its own right. ${ }^{48}$

\section{OPPOSING ABUSES}

This brings us to a difficult question: how wrong is failing to oppose known abuses? There are three situations. The first is the case of historians participating in abusive operations themselves. Not opposing such operations is clearly wrongdoing. The second situation arises when works of historians are abused against the latter's will. These historians cannot, of course, be held accountable for the abuse of others. If, however, they become aware that their published work is being abused by third parties and if they are free to speak, they should stand up and denounce the abuse of their work. The third case is the most difficult: do historians in general have the duty to oppose known abuses of colleagues? It is reasonable to restrict the category 'historians in general' to those who are experts in the field in which the abuse occurs. Thus, the initial question can be reformulated as follows: do specialized historians have the duty to oppose a known abuse in their field? In principle, failing to oppose a known abuse and bogus history is failing to exercise the professional duty of accountability. In practice, however, circumstances are sometimes less simple. First, there may be tough psychological factors at work: inertia, underestimation of the phenomenon of abuse, ill-conceived collegiality, or the incredulity that abuses occur in one's own branch of specialization. Second, there is the sheer volume of work resting on the shoulders of 
individual historians, which may delay exposure of known abuse, especially because standards of proof are - and should be - high. Third, the experts in question are often rivals or colleagues of the abusers. And sometimes they find themselves in positions of subordination vis-à-vis the abusers.

Disclosing abuses, therefore, usually requires exacting courage. This is obviously so under dictatorships. It even is in more open surroundings when disclosing means reporting these abuses confidentially to an ombudsperson or to some ethics advisory committee. The experience of whistleblowers those releasing well-founded information on wrongdoing - in democracies is not very reassuring. All too often, they risk becoming targets of campaigns themselves (and some of these campaigns may be instigated by powerful abusers). Fear of being sued for defamation or other tactics of intimidation have traditionally been powerful motives not to react to abuse. ${ }^{49}$ Experts, therefore, can sometimes invoke attenuating circumstances. From this discussion, two conclusions follow. First, it is important to see the subtle but important distinction between opposing abuse and disclosing it. Opposition to abuse encompasses several activities: disclosure, refutation, sanction, and prevention. Second, the fact that even individual specialists need much courage to denounce abuse, renders the collaboration among historians in terms of organization and procedures necessary.

Historians who formulate the academic ethic, when trying to sum up what is really at stake in cases of grave abuse of history, should remember the words of Voltaire: "Those who can make you believe absurdities, can make you commit atrocities." 50

\section{NOTES}

${ }^{1}$ CICERO, Marcus Tullius, De oratore I, II (originally Latin, 55 BCE; translation E.W. Sutton; Cambridge, MA: Harvard University Press; London: Heinemann, 1976), II, 62 (242-245). The present essay is an updated version of pages 9-39 of DE BAETS, Antoon, Responsible History (New York; Oxford: Berghahn Books, 2009). All websites mentioned were last accessed on 15 Dec. 2012.

${ }^{2}$ International Committee of Historical Sciences, Constitution (available at www.cish.org/ EN/presentation/constitution.htm; 1926, as amended in 1992 and 2005), Article 1.

${ }^{3}$ For example, FERRO, Marc, The Use and Abuse of History, or How the Past Is Taught to Children (London; Boston: Routledge, 2003); FINLEY, Moses, The Use and Abuse of 
History (London: Chatto \& Windus; New York: Viking, 1986); GEYL, Pieter, The Use and Abuse of History (New Haven, CT: Yale University Press, 1955); LEWIS, Bernard, History Remembered, Recovered, Invented (Princeton, NJ: Princeton University Press, 1987); TODOROV, Tzvetan, “The Abuses of Memory," Common Knowledge, 5, no. 1 (Spring 1996), 6-26. My own analysis of the censorship of history was also centered on the basic notion of legitimation. See DE BAETS, Antoon, Censorship of Historical Thought: A World Guide 1945-2000 (Westport, CT; London: Greenwood, 2002), 1-36. Essays by Friedrich Nietzsche and W.B. Gallie carrying the phrase "use and abuse of history" in their titles do not deal with abuse as understood here. Throughout this essay, I have generally deliberately abstained from giving concrete examples of abuses. For many examples, see DE BAETS, Censorship, passim.

${ }^{4}$ More background in ALTBACH, Philip, "The Academic Profession," in ALTBACH, ed., International Higher Education: An Encyclopedia, vol. 1 (New York; London: Garland, 1991), 23-45.

${ }^{5}$ KUSÝ, Miroslav, "On the Purity of the Historian's Craft," Kosmas, 1984-1985, III, no. 2 \& IV, no. 1, 29-31, 38. He referred to BLOCH Marc, Apologie pour l'histoire ou métier d'historien (originally 1949; Paris: Colin, 1967) and CARR, Edward. What Is History? (originally 1961; Harmondsworth: Penguin, 1973).

${ }^{6}$ DAVIS, Natalie Zemon, "Censorship, Silence and Resistance: The Annales during the German Occupation of France," Historical Reflections, 24, no. 2 (Summer 1998), 351-374.

${ }^{7}$ This is partly the case in the (interesting) piece of WIRTH, Laurent, "Facing Misuses of History," in The Misuses of History (Strasbourg: Council of Europe [Council for Cultural Co-operation], 2000), 23-56. Wirth approaches, however, the core of the problem when discussing intentional omission (pages 46-47.)

${ }^{8}$ SHILS, Edward, The Calling of Education: The Academic Ethic and Other Essays on Higher Education, ed. Steven Grosby (Chicago: Chicago University Press, 1997), 160-161. John Dewey expressed the same idea in 1902. See his "Academic Freedom" (1902) in BOYDSTON, Jo Ann, ed., John Dewey: The Middle Works, 1899-1924, volume 2, 19021903 (Carbondale; Edwardsville: Southern Illinois University Press; and London; Amsterdam: Feffer \& Simons, 1976), 55. On the value of truth, see WILLIAMS, Bernard, Truth \& Truthfulness: An Essay in Genealogy (Princeton; Oxford: Princeton University Press, 2002), 6-7.

${ }^{9}$ POPPER, Karl, Logic of Scientific Discovery (London: Hutchinson, 1980), 34-42 and 278282; and POPPER, Conjectures and Refutations: The Growth of Scientific Knowledge (London: Routledge \& Kegan Paul, 1963, 1974), 33-41, 253-258. For an overview of demarcation theories, see TRUZZI, Marcello, "Pseudoscience," in Gordon Stein, ed., The Encyclopedia of the Paranormal (Amherst, NY: Prometheus, 1996), 560-574, and DOLBY, Riki, Uncertain Knowledge: An Image of Science for a Changing World (Cambridge, etc.: Cambridge University Press, 1996), 159-165, 184-225. See also STUMP, David, 
"Pseudoscience," in HOROWITZ, Maryanne, ed. New Dictionary of the History of Ideas, vol. 5 (Detroit: Scribner's, 2005), 1950-1951. Dolby enumerated the following demarcation principles: authoritative classification (Auguste Comte), induction (John Stuart Mill), convention (Henri Poincaré), operationalism (Percy Bridgman), true protocol statements (logical positivists), falsifiable hypotheses (Karl Popper), progressive research programs (Imre Lakatos), heuristic value (pragmatists), correct ideology (Marxists), and no demarcation (Paul Feyerabend). See DOLBY, Uncertain Knowledge, 163-164.

${ }^{10}$ The power of myths to give meaning is clear from George Schöpflin's taxonomy, which distinguishes eight motifs in myths: territory; redemption and suffering; unjust treatment; election and civilizing mission; military valor; rebirth and renewal; ethnogenesis and antiquity; and kinship and shared descent. See his "The Functions of Myth and a Taxonomy of Myths," in HOSKING, Geoffrey \& SCHÖPFLIN, George, eds., Myths and Nationhood (London: Hurst, 1997), 28-35. See also LOWENTHAL, David, "Fabricating Heritage," History \& Memory, 10, no. 1 (Spring 1998), 5-25. For further reflections on myths, see MCNEILL, William, "Mythistory, or Truth, Myth, History, and Historians," American Historical Review, 91, no. 1 (Feb. 1986), 6-9; for reflections on the excusability of historical myths, see GORDON, David, Self-determination and History in the Third World (Princeton, NJ: Princeton University Press, 1971), 177-182; for reflections on the coexistence of contradictory beliefs in the human mind, see VEYNE, Paul, Les Grecs ont-ils cru à leurs mythes? Essai sur l'imagination constituante (Paris: Seuil, 1983).

${ }^{11}$ See WILLIAMS, Bernard, Truth \& Truthfulness, 84-148. See also my Responsible History, 173-196, which attempts to operationalize the concept.

${ }^{12}$ For the concept of deception (and the distinction with self-deception), see BEVIR, Mark, The Logic of the History of Ideas (Cambridge, Cambridge University Press, 1999), 265-78. Bevir defines deception as the attempt to make others believe something the deceiver believes to be false (page 267).

${ }^{13}$ FEINBERG, Joel, Harm to Others (New York; Oxford: Oxford University Press, 1984), 187-191.

${ }^{14}$ Applying Immanuel Kant's argument in "On a Supposed Right to Lie from Altruistic Motives" (originally German 1785), in SINGER, Peter, ed., Ethics (Oxford: Oxford University Press, 1994), 281: "For a lie always harms another; if not some other particular man, still it harms mankind generally, for it vitiates the source of law itself." For criticism of Kant's thesis, see WILLIAMS, Truth \& Truthfulness, 84-85, 117.

${ }^{15}$ See also BARENDT, Eric, Freedom of Speech (fully revised and updated second edition; Oxford: Oxford University Press, 2005), 226.

${ }^{16}$ See DE BAETS, Responsible History, chapter 3. See also Henry SIDGWICK's important observations in his The Methods of Ethics (originally 1874; seventh edition 1907; Indianapolis; Cambridge: Hackett, reprint 1981), 312-319, 485. 
${ }^{17}$ GROSS, Hyman, A Theory of Criminal Justice (New York: Oxford University Press, 1979), 13-18.

${ }^{18}$ See also SHILS, Calling of Education, 160-161; SCHAUER, Frederick, Free Speech: A Philosophical Inquiry (Cambridge: Cambridge University Press, 1982), 92, 102.

${ }^{19}$ Illegal abuses are restricted by several rights or laws. Regarding the author who is abused: the right to free expression, copyright laws; regarding the message content: the right to freedom of information, data protection laws, archival laws; regarding the historians' subjects: the rights to privacy and reputation, hate speech provisions. For example, many abuses involving the deceptive use of work of others amount to a type of invasion of privacy called 'false light': 'false light' is the case when the opinions of others are distorted or when the others are falsely associated with findings they do not share.

${ }^{20}$ For a survey of pseudohistorical theories (like Holocaust denial, afrocentrism, creationism, archaeological fraud, etc.), see CARROLL, Robert, The Skeptic's Dictionary (Hoboken, NJ: Wiley, 2003); CORINO, Karl, ed., Gefälscht! Betrug in Politik, Literatur, Wissenschaft, Kunst und Musik (Reinbek: Rowohlt, 1992); FEDER, Kenneth, Frauds, Myths, and Mysteries: Science and Pseudoscience in Archaeology (Mountain View, CA, London; Toronto: Mayfield, 1999); FULD, Werner, Das Lexikon der Fälschungen (Frankfurt am Main: Eichborn, 1999); William WILLIAMS, ed., Encyclopedia of Pseudoscience (Chicago; London: Fitzroy Dearborn, 2000).

${ }^{21}$ See, among others, WOOLF, Daniel, "Historiography," in HOROWITZ, ed., New Dictionary, vol. 1, passim, for examples.

${ }^{22}$ WATT, Donald Cameron, "The Political Misuse of History," Trends in Historical Revisionism: History As a Political Device (London: Centre for Contemporary Studies, 1985), 11. See also SABROW, Martin, JESSEN, Ralph \& GROßE KRACHT, Klaus, eds., Zeitgeschichte als Streitgeschichte: Grosse Kontroversen seit 1945 (Munich: Beck, 2003), 9-18.

${ }^{23}$ DE BAETS, Antoon, “Archives," in Derek JONES, ed., Censorship: A World Encyclopedia (London; Chicago: Fitzroy Dearborn, 2001), 76-82.

${ }^{24}$ This is the domain of historical propaganda: the systematic manipulation of historical facts or opinions, usually by, or with the connivance of, the government or another power; see DE BAETS, Censorship, 18.

${ }^{25}$ Related to irresponsible omission is the notion of historical taboos: historical facts or opinions that cannot be mentioned for reasons of privacy, reputation, or the legitimation of power and status. For definitions of concepts related to the abuse of history, see DE BAETS, Antoon, "Taxonomy of Concepts Related to the Censorship of History", in MARET, Susan, ed., Government Secrecy, Series Research in Social Problems and Public Policy (Bingley: Emerald) no. 19 (2011), 53-65, or idem, "Censorship Backfires: A Taxonomy of Concepts Related to Censorship," in HUFF, Mickey \& ROTH, Andy Lee, with Project Censored, eds., Censored 2013: Dispatches From the Media Revolution (New York: Seven Stories Press, 2012), 223-234. 
${ }^{26}$ For background to the discussion about narrative in historiography, see LORENZ, Chris, "History: Forms of Representation, Discourse, and Functions," in SMELSER, Neil, \& BALTES, Paul, eds., International Encyclopedia of the Social and Behavioral Sciences, vol. 10 (Oxford, etc.: Elsevier-Pergamon, 2001), 6836-6842.

${ }^{27}$ American Historical Association, Statement on Standards of Professional Conduct (available at www.historians.org/pubs/free/ProfessionalStandards.cfm; Washington, May 1987; entirely revised Jan. 2011); Berne Convention for the Protection of Literary and Artistic Works (available at www.wipo.int/treaties/en/ip/berne/trtdocs_wo001.html; Berne; Paris: World Intellectual Property Organization, 1886, 1979), Articles 3, 6bis-7bis, 10, 15-16; BERNHEIM, Ernst, Lehrbuch der Historischen Methode und der Geschichtsphilosophie (Leipzig: von Duncker \& Humblot, 1903), 300-358; BLOCH, Apologie, 41-52; BROAD, William \& WADE, Nicholas, Betrayers of the Truth (New York: Simon and Schuster, 1982), 29; BRUGIONI, Dino, Photo Fakery: The History and Techniques of Photographic Deception and Manipulation (Dulles, VA: Brassey's, 1999), 196-202; CHUBIN, Daryl, \& HACKETT, Edward, Peerless Science: Peer Review and US Science Policy (Albany: State University of New York Press, 1990), 136; ECO, Umberto, "Fakes and Forgeries," in ECO, The Limits of Interpretation (Bloomington; Indianapolis, IN: Indiana University Press, 1990), 174-202; FISCHER, David, Historians' Fallacies: Toward a Logic of Historical Thought (New York etc.: Harper Torchbooks, 1970), 82-87; GRAFTON, Anthony, Forgers and Critics: Creativity and Duplicity in Western Scholarship (Princeton, NJ: Princeton University Press, 1990), 3668; HAYWOOD, Ian, Faking It: Arts and the Politics of Forgery (Brighton: Harvester Press, 1987), 1-18, 131-143; JAUBERT, Alain, Le Commissariat aux archives: les photos qui falsifient l'histoire (Paris: Barrault, 1986); KURZ, Otto, Fakes: A Handbook for Collectors and Students (London: Faber and Faber, [1948]), 316-321; LAFOLLETTE, Marcel, Stealing into Print: Fraud, Plagiarism, and Misconduct in Scientific Publishing (Berkeley; Los Angeles: University of California Press, 1992), 32-67; LANGLOIS, Charles-Victor \& SEIGNOBOS, Charles, Introduction aux études historiques (originally 1898; Paris: Éditions Kimé, 1992), 133-158; OUY, Gilbert, "Les Faux dans les archives et les bibliothèques," in SAMARAN, Charles, ed., L'Histoire et ses méthodes (Paris: Gallimard, 1961), 1367-1383; PRADEL, Pierre, "Les Musées: l'authenticité des témoignages - faux et demi-faux," in SAMARAN, ed., L'Histoire et ses méthodes, 1784-1789; VANSINA, Jan, Oral Tradition As History (London: James Currey, 1985), 95-114.

${ }^{28}$ See, among others, WILLIAMS, Glanville, The Mental Element in Crime (Jerusalem: Magnes Press, 1965), 20.

${ }^{29}$ Also failures to act can occur either purposely, knowingly, recklessly, or negligently. See the diagram in FEINBERG, Joel, Harm to Others (New York; Oxford: Oxford University Press, 1984), 257-258n34.

${ }^{30}$ See also NICKELL, Joe, Pen, Ink, \& Evidence: A Study of Writing and Writing Materials for the Penman, Collector, and Document Detective (originally 1990; New Castle, DE: Oak Knoll Press, 2000), 192-194 (“genuine fakes”). 
${ }^{31}$ MENDEL, Toby, Study on International Standards Relating to Incitement to Genocide or Racial Hatred-For the UN Special Advisor on the Prevention of Genocide (N.p., Apr. 2006), 49.

${ }^{32}$ See also LAFOLLETTE, Stealing into Print, 47, 60. For reflections on the boundaries of sound historical scholarship, see KOCKA, Jürgen, "Objektivitätskriterien in der Geschichtswissenschaft," in KOCKA, Sozialgeschichte (Göttingen: Vandenhoeck \& Ruprecht, 1977), 40-47, and BROWN, Donald, Hierarchy, History \& Human Nature: The Social Origins of Historical Consciousness (Tucson AZ: The University of Arizona Press, 1988), 10-15. Likewise, I identified six types of restrictions put upon historians living in democracies that form borderline cases of censorship: see DE BAETS, Censorship, 6-10.

${ }^{33}$ GARNER, B.A., ed. Black's Law Dictionary, (originally 1891; St. Paul, MN: West Group, 2004), 825.

${ }^{34}$ Table 3 offers a comprehensive overview of authors' motives for writing history. As motives of authors are indicators for the motives of readers, the table also reflects types of motives for reading history. Therefore, it also globally indicates the social functions, meaning, and utility (or 'uses') of historical writing. The table also happens to contain implicitly many motives for deception. I hope, therefore, that it refutes, partially at least, Marc Bloch's belief (BLOCH, Apologie, 43) that it would be in vain to enumerate the range of motives that persons may have to lie.

${ }^{35}$ BERNHEIM, Lehrbuch, 301-302; BLOCH, Apologie, 43; FEDER, Frauds, 9-10; GALLIE, W.B., "The Uses and Abuses of History," in GALLIE, Philosophy \& the Historical Understanding (originally 1964; New York: Schocken Books, 1968), 126-139; GRAFTON, Forgers and Critics, 37-49; HAYWOOD, Faking It, 8-9; KURZ, Fakes, 318-319; KARLSSON, Klas-Göran, "Public Uses of History in Contemporary Europe," in JONES, Harriet, ÖSTBERG, Kjell, \& RANDERAAD, Nico, eds., Contemporary History on Trial: Europe Since 1989 and the Role of the Expert Historian (Manchester; New York: Manchester UP, 2007), 34; LANGLOIS \& SEIGNOBOS, Introduction, 141-145; VANSINA, Oral Tradition, 91-93.

${ }^{36}$ See for the political use and abuse of history, for example, "Historical Consciousness and Political Action," History and Theory, 17, no. 4 (Dec. 1978) (theme issue).

${ }^{37}$ The only authors who make the essential distinction between intent and motive are BEVIR, The Logic, 286-304, and BROWN, Elizabeth, "Falsitas pia sive reprehensibilis: Medieval Forgers and Their Intentions," in Fälschungen im Mittelalter, vol. 1 (Hannover: Hahnsche Buchhandlung, 1988), 103.

${ }^{38}$ See also PORK, Andrus, "History, Lying and Moral Responsibility," History and Theory, 29, no. 3 (Oct. 1990), 329.

${ }^{39}$ For the distinction between facts and opinions, see DE BAETS, “Taxonomy," 55.

${ }^{40}$ See, for example, NICKELL, Pen, Ink, \& Evidence, 186-194 ("Questioned documents"). 
${ }^{41}$ See FISCHER, Historians' Fallacies, xvii and 306, for the distinction between abuse and logical error / fallacy.

${ }^{42}$ For examples of blameworthy negligence, see WIENER, Jon, Historians in Trouble: Plagiarism, Fraud, and Politics in the Ivory Tower (New York; London: The New Press, 2005), 71-116.

${ }^{43}$ Alfred Housman as quoted in CARR, What Is History?, 10.

${ }^{44}$ This is the case of historian Ferdinand Nahimana. See International Criminal Tribunal for Rwanda, Prosecutor v. Ferdinand Nahimana, Jean-Bosco Barayagwiza, Hassan Ngeze; Case no. ICTR-99-52-T: Judgement and Sentence (available at www.concernedhistorians. org/le/64.pdf; 2003), especially paragraphs 5, 8, 13, 620-696, 978-1033, 1091-1105. The tribunal said (in paragraph 1099): "Ferdinand Nahimana was a renowned academic...[H]e betrayed the trust placed in him as an intellectual and a leader."

${ }^{45}$ YERUSHALMI, Yosef, Zakhor: Jewish History and Jewish Memory (New York: Schocken, 1989), 116.

${ }^{46}$ See ERDMANN, Karl, KOCKA, Jürgen \& MOMMSEN, Wolfgang, Toward a Global Community of Historians: The International Historical Congresses and the International Committee of Historical Sciences, 1898-2000 (New York; Oxford: Berghahn, 2005), 142-143 (on the Charter of 6 July 1932), 330, 397, 400 (amendments of the Constitution of 1992 and 2005).

${ }^{47}$ I am grateful to Jean-Claude Robert, secretary-general of the International Committee of Historical Sciences (2000-2010), for clarifying the history of the different versions of the clause (e-mail correspondence of 22, 24, and 25 Sep., 1 and 3 Oct., 26 and 28 Nov. 2006). See for that history the following minutes available at www.cish.org/EN/presentation/ board.htm: (1) the Bureau meeting (Oslo, 13 Aug. 2000), item 5 (“Other matters," regarding the Indian situation); (2) the Bureau meeting (Paris, 30-31 Aug. 2003), which concluded item 9.3 ("History research in India") in the following terms: "The Sydney Congress [of 2005] should prominently deal with the present problem of the relationship between politics and history, including censorship and political intervention into the discipline"; (3) the "Bureau restreint" meeting (Lausanne; Crans, 21-22 Feb. 2004), which under item 2 ("ICHS operations / amendments to the statutes") spoke of 'abuse of history' and also stated: "The advantage of the new wording [i.e., 'abuse'] is that it spells out the ICHS's attitude towards the use of history for political ends"; (4) the Bureau meeting (Berlin, 27-28 Aug. 2004), which under item 3.1 ("Motion to amend the statutes of the ICHS: Article 1") changed 'abuse' into 'misuse'; (5) the General Assembly (Sydney, 3 July 2005), which under item 6 ("Amendments to the statutes of the ICHS") spoke of 'abusive use.' In the final text, the term 'misuse' was chosen. For the situation of history under the Bharatiya Janata Party in India, see, for example, THAPAR, Romila, "Politics and the Rewriting of History in India," Critical Quarterly, 47, nos. 1-2 (July 2005), 195-203.

${ }^{48}$ See also Council of Europe (Parliamentary Assembly), History and the Learning of History 
in Europe: Report (Doc. 7446) (available at www.assembly.coe.int/ASP/Doc/ XrefViewHTML.asp?FileID=7037\&Language=EN; 1995), paragraph 40: "Any abuse of history should be combated and avoided."

${ }^{49}$ GROSSBERG, Michael, "Plagiarism and Professional Ethics: A Journal Editor's View," Journal of American History, 90, no. 4 (March 2004), 1337-1338.

${ }^{50}$ VOLTAIRE, Questions sur les miracles (1765), here "Onzième lettre écrite par le proposant à M. Covelle." According to http://en.wikiquote.org/wiki/Voltaire, this famous quotation is an adaptation from "Certainement qui est en droit de vous rendre absurde est en droit de vous rendre injuste" (to be translated as "Truly, whoever is able to seduce you to absurdity, is able to seduce you to injustice.")

Article received on 26 October 2012. Approved on 29 November 2012. 